\title{
Internet w służbie samorządu czy samorządowców? Na podstawie zawartości stron internetowych małych gmin w samorządowej kampanii wyborczej 2014 roku
}

Streszczenie: Powszechną jest opinia, ze urzędującemu kandydatowi jest łatwiej wygrać wybory. Ma on już jakieś osiagnięcia, elektorat go zna. Ma także aparat urzędniczy i media, których może użyć w kampanii. W artykule przedstawiono wyniki analizy zawartości stron internetowych małych gmin w trakcie kampanii wyborczej 2014 roku. Próbowano odpowiedzieć na pytanie: Czy strony internetowe samorządów promują gminę, czy może są traktowane instrumentalnie przez urzędujących wójtów i służą ich autopromocji?

Słowa kluczowe: Samorząd terytorialny, Internet, kampania wyborcza, marketing polityczny, PR

\section{Komunikowanie polityczne w wersji samorządowej}

Tomunikowanie jest pojęciem nadrzędnym w stosunku do takich - procesów jak propaganda, public relations, reklama czy kampania polityczna i wyborcza (Dobek-Ostrowska, 2011, s. 132). PR jest definiowany dwojako. Specjaliści od marketingu traktują go jako zespół technik komunikowania marketingowego, natomiast teoretycy komunikowania definiują PR jako formę procesu komunikowania między instytucjami a ich publicznościami (Dobek-Ostrowska, 2011, s. 133). Rynkowy PR jest nastawiony na konsumenta, który ma kupować więcej towaru (niekoniecznie potrzebnego). PR w administracji publicznej uzależniony jest od definiowania jej celów. Przykładowo New Public Management próbuje zbliżyć administrację publiczną do gospodarki rynkowej, a gminy do produktu rynkowego (Duda, 2010, s. 22). Zadania administracji traktuje się jako dostarczanie usług mieszkańcom. Usługą jest zatem zapewnienie edukacji, dostępności do lekarza czy wypożyczanie książek w bibliotece. 
Człowiek jest zatem „konsumentem” „usług publicznych”. Oczekuje od „dostarczyciela usług” profesjonalizmu, wysokiego poziomu tejże usługi itd. Z drugiej jednak strony nie można zapominać o obywatelu i jego potrzebach. W demokratycznych procesach decyzyjnych uczestniczy człowiek-obywatel, a nie człowiek-konsument. Bycie obywatelem oznacza bycie członkiem szerszej społeczności, zaangażowanym w życie ogółu. Instytucje publiczne powinny zatem - przy pewnej analogii do rynkowości usług - realizować także cele wyższe, dbać o dobro wspólne (Duda, 2010, s. 23). Drugi kierunek rozwoju zarządzania w administracji publicznej to dobre rządzenie (Good Governance). Dobre rządzenie można zdefiniować jako uczestnictwo, legitymację, przejrzystość, skuteczność, efektywność, odpowiedzialność, dyspozycyjność, przewidywalność i spójność działań administracji publicznej (Folga, s. 84).

Administracja publiczna działa w szczególnych warunkach $-\mathrm{z}$ jednej strony mamy monopol (państwowa), a z drugiej - konkurencję (samorządowa). Instytucje dążą do zapewnienia sobie akceptacji ze strony społeczeństwa i wykorzystują w tym celu public relations. Jeżeli działalność jest skuteczna, to jej efektem będzie dobry wizerunek i życzliwość wobec wymyślonej wizji i zadeklarowanej misji (Knecht, 2006, s. 36). Misją nadrzędną całej administracji jest m.in. zapewnienie spokojnego i godnego życia mieszkańcom. Od władzy lokalnej oczekuje się właściwego, empatycznego i etycznego rozwiązywania problemów (Knecht, 2006, s. 37).

Obecnie wydaje się, że najwłaściwszym sposobem komunikowania jest IMC (Integrated Marketing Communications). Koncepcja ta polega na koordynowaniu różnych elementów promocyjnych i innych działań marketingowych, za pomocą których organizacja komunikuje się z otoczeniem, w celu wygenerowania wyrazistego, koherentnego i przykuwającego uwagę przekazu (Szymańska, 2006, s. 171). Połączenie dotychczas odrębnych dziedzin, czyli marketingu i public relations, tworzy marketingowe public relations. Jest ono postrzegane jako węższy aspekt PR, którego celem jest bezpośrednie wspieranie promocji przedsiębiorstwa/ produktu, kształtowanie image, przekazywanie wiarygodnych informacji i wspieranie działań na rzecz społeczeństwa (Szymańska, 2006, s. 189). Wiarygodność MPR jest przy tym wyższa od marketingu, przez co łatwiej (bez balastu nachalnej reklamy) jest wypromować markę.

Rozwój lokalny jest sprowadzony do rozwoju gospodarczego. Można go stymulować przez marketing terytorialny (komunalny, miejski, gminny). Ten rodzaj marketingu społecznego ukierunkowany jest na zadowolenie klienta, czyli bardziej przypomina, opisywane wyżej, nowe zarzą- 
dzanie publicznie niż dobre rządzenie. Jednostka terytorialna funkcjonuje w sposób zbliżony do przedsiębiorstwa - dostarcza produkty i usługi, aby zaspokoić potrzeby konsumentów (Piasecki, 2009, s. 328-329). Podstawowym zadaniem marketingu terytorialnego jest rozwój danej przestrzeni, poprzez kreowanie rynku, a dokładniej popytu (Duczkowska-Piasecka, 2013, s. 70). Małgorzata Duczkowska-Piasecka wymienia siedem grup aktorów mających największe znaczenie dla rozwoju marketingu, na pierwszych pozycjach sytuując przedsiębiorców i inwestorów, a na ostatniej obywateli (2013, s. 139-141). Natomiast wśród klientów (11 pozycji) na czołowych miejscach wyróżnia potencjalnych przedsiębiorców i inwestorów, na 6-7 miejscu mieszkańców stałych i okazjonalnych, a na ostatnim turystów (Duczkowska-Piasecka, 2013, s. 145-147).

Z powyższego wynika, że samorządy konkurują ze sobą z jednego powodu - chcą przyciagnąć jak najwięcej inwestorów, którzy dzięki inwestycjom, zostawią w gminie swoje pieniądze i wykreują miejsca pracy. Cele te można zrealizować poprzez zdobywanie środków zewnętrznych oraz poprzez tworzenie sprzyjających warunków dla biznesu (Czarnecka, s. 66-67).

Istotę działań PR samorządów potwierdzają badania Anety Dudy (2008, s. 39-41). Zapytała ona urzędników samorządowych z 6 województw o różne kwestie związane z PR. Na pytanie o zadania PR najistotniejsze dla instytucji, najwięcej wskazań padło na „,informowanie społeczności o działaniach instytucji” oraz „kształtowanie pozytywnego wizerunku instytucji”. Z kolei w kwestii bardziej ogólnie sformułowanych obszarów działań PR najczęściej respondenci wskazywali ,promocję gospodarczą i inwestycyjną”, „kontakty i współpracę ze społecznością lokalną” oraz ,promocję turystyczną”. Inne wyniki podaje Krzysztof Marcinkowski (2008, s. 195), który przebadał gminy powiatu poznańskiego. Zdaniem urzędników gminnych działania PR ich urzędów powinny być skierowane do „mieszkańców” (80\%) i ,petentów” (85\%), natomiast „zewnętrzni przedsiębiorcy" otrzymali tylko 55\% wskazań, czyli mniej niż „turyści” i „nowi mieszkańcy”.

Skoro promocja gminy ma służyć przyciagnięciu inwestorów, to dlaczego samorządy inwestują w imprezy kulturalne czy sportowe, które w bardzo niewielkim stopniu przyczyniają się do ich rozwoju? Te wydarzenia mogą współtworzyć wizerunek miejscowości czy regionu, ale w bezpośredni sposób nie przekładają się na rozwój. Sprzeczne wyniki przedstawione powyżej sugerują dwoistość działań samorządów. Tak też jest $\mathrm{w}$ istocie; kompleksowe strategie promocji powinny przewidywać 
dwa kierunki komunikowania: zewnętrzny - nastawiony na inwestorów i turystów oraz wewnętrzny - np. zwiększający identyfikację mieszkańców ze swoją miejscowością (Przepióra, 2103, s. 134). Władze uważają, że należy mówić o przyciaganiu inwestorów, o rozwoju, o nowych miejscach pracy, o wykorzystaniu środków unijnych - to ładnie wygląda, szczególnie kiedy otrzymuje się nagrody za dobre pozyskiwanie środków zewnętrznych. Z drugiej jednak strony ludziom trzeba dać igrzyska, stąd różnego rodzaju festiwale chleba i kapusty, darmowe wakacyjne koncerty gwiazd i gwiazdeczek estrady, zapraszanie stacji telewizyjnych na dni miejscowości itd. Z punktu widzenia marketingu miejsca, to działania słuszne, budujące wizerunek marki. Mają one jednak bardziej wymiar pragmatyczny - można je wykorzystać wyborczo. Urzędnicy gminni wiedzą doskonale, że jak mieszkańcy będą zadowoleni (,bo coś się dzieje"), to wybiorą na kolejną kadencję wójta, a ten utrzyma skład osobowy swojego urzędu.

Samorządy, szczególnie gminne, działają na oślep. Mają co prawda przyjęte przez rady gminy $\mathrm{w}$ formie uchwał różnego rodzaju strategie rozwoju, ale nie mają strategii PR. W badaniu przeprowadzonym przez Rafała Przecha w 2007 r. na 52 gminach 4 województw okazało się, że aż 50 gmin nie posiadało strategii PR (Przech, 2007). Pierwszym krokiem, który należy zrobić w każdej strategii, jest przygotowanie badań rynku, aby wiedzieć do kogo należy późniejsze działania skierować, jakie angażować środki itd. (Langer, 2008, s. 152-153; Kolbus, 2013, s. 130-136). Gminy w większości (68\%) nie prowadzą badań efektywności polityki promocyjno-informacyjnej, ponieważ nie wiedzą jak można to zbadać lub nie widzą potrzeby takich badań (Marcinkowski, 2008, s. 197). Stąd też w działaniach samorządów mamy chaos i intuicję zamiast profesjonalizmu i podstaw merytorycznych. Kolejnym problemem ze strategiami rozwoju gmin jest także konieczność ich korelacji ze strategiami powiatów i województw (Piasecki, 2009, s. 324).

Powyżej omówiono różne aspekty public relations, promocji i zarządzania publicznego. W polskiej literaturze można znaleźć liczne próby definiowania marketingu politycznego. Zbiór definicji przedstawiają, przykładowo: Wojciech Cwalina i Andrzej Falkowski (2005), Dorota Piontek (2003) czy ostatnio Jarosław Zieliński (2013). W odniesieniu do samorządu terytorialnego, zdaniem Andrzeja Piaseckiego (2007, s. 299), najbliższa będzie definicja sprowadzająca marketing polityczny do czterech elementów: umiejętnego wykorzystania badań do zrozumienia środowiska politycznego, skutecznego i efektywnego zaprezentowa- 
nia produktu (kandydata) jego konsumentowi (wyborcy), wykorzystania wszystkich możliwych i etycznie dopuszczalnych metod i strategii marketingowych w celu sprzedaży produktu w dniu wyborów i penetrowania rynku wyborczego przez środki masowego przekazu.

Jeszcze przed 2002 rokiem (kiedy wprowadzono bezpośrednie wybory wójta), wójtowie stawali się lokalnymi liderami. Wprowadzenie bezpośredniości wyboru wzmocniło personalne akcenty w marketingu samorządowym i to wizerunek kandydata i jego kreacja, stał się najważniejszym elementem marketingu. Można wskazać kilka elementów budujących wizerunek kandydata, np. głębokie przekonanie, iż to, co robi polityk jest zgodne z oczekiwaniami wyborców, samoświadomość własnych kompetencji, atrakcyjność interpersonalna, atrakcyjność własnej oferty itp. (Piasecki, 2007, s. 300).

Zdaniem Jerzego Bartkowskiego (2007, s. 283) najważniejszymi powodami, dla których wyborcy oddają swój głos na polityka są jego dotychczasowe sukcesy, transfer do polityki opinii środowiskowo-zawodowej i oceny jednostki w życiu prywatnym. Intensywna kampania wyborcza otrzymuje najmniej wskazań. Wyborcy nie szukają programów, a ludzi - głosują na ludzi doświadczonych, których znają.

\section{Wykorzystanie Internetu w komunikacji politycznej}

Administracja publiczna, w tym samorządowa, czy szerzej - władza publiczna, na gruncie Konstytucji RP, powinna działać w myśl zasady legalizmu (Grzybowski, 2005, s. 32-34). Gmina, jako administracja publiczna podstawowego szczebla samorządowego, wykonuje zadania nałożone na nią przez ustawodawcę w ustawie o samorzadzie gminnym (tekst jedn. Dz. U. 2013, poz. 594). Do zakresu działania gminy należą zatem wszystkie sprawy publiczne o znaczeniu lokalnym (art. 6 ust. 1), a art. 7 ust. 1 wymienia szczególne zadania gminy, wśród których znaleźć można wspieranie i upowszechnianie idei samorządowej czy promocję gminy.

W myśl Konstytucji RP, każdy obywatel ma prawo do uzyskiwania informacji o działalności organów władzy. Informacją publiczną jest każda informacja o sprawach publicznych (art. 1 ust. 1 UDIP, 2014; Kowalczyk, 2009, s. 21-37). Ustawą z dnia 6 września 2001 roku o dostępie do informacji publicznej nałożono na jednostki administracji publicznej obowiązek posiadania własnych serwisów internetowych (Nowina Konopka, 
2011, s. 187), jako Biuletynu Informacji Publicznej. BIP jest zatem jedynym obowiązkowym zbiorem informacji, w którym należy zamieszczać wszystko co dotyczy władzy publicznej (z pewnymi wyłączeniami, jak np. dane osobowe) (Butkiewicz, 2006, s. 75).

Czy gminy, jako organy władzy publicznej, mają prawo zamieszczać informacje w innych serwisach internetowych niż BIP? Z punktu widzenia ustawy o dostępie do informacji publicznej nie. W przypadku samorządów gminnych należy jednak przywołać, wspomniane wyżej, zadania własne, w tym m.in. ,promocję gminy”. Idąc tym tropem, można dopuścić prowadzenie przez gminy serwisów innych niż BIP. Będą one jednak pełniły rolę promocyjną i tak należałoby je analizować i oceniać. Nie należy przypisywać im roli „oficjalnych” informacji, w sensie „urzędowych", czyli mających moc urzędową, wydawanych na podstawie prawa, które np. można zaskarżyć w sądzie administracyjnym. Te należy ogłaszać w BIP-ie, z podpisem osoby, która daną informację wytworzyła, wprowadziła, z podaniem daty i godziny ogłoszenia itd., a nie na „oficjalnej stronie urzędu gminy X".

Analizą zawartości stron internetowych urzędów samorządowych różnych szczebli zajmowało się dotychczas kilku badaczy. Niektórych wymienia Leszek Porębski (2012, s. 119-124), przykładowo: Agnieszka Pawłowska i Marcin Sakowicz (2003), Jerzy Bański (2006), czy Stanisław Ceran i Michał Sidoruk (2006). Można także wskazać: Aleksandrę Krawczyk (2014), Elżbietę Kozubek i Piotra Wernera (2009), Tomasza Gajowniczka (2013). Najczęściej do analizy wykorzystywane są dwa narzędzia: WAES (Marjak, 2008) i KOZWIS. Ten drugi, Kwestionariusz Oceny Zawartości Witryn Instytucji Samorządowych, opracowany przez L. Porębskiego (2012, s. 129), służy badaniu witryn internetowych pod względem wypełniania przez nie czterech funkcji: informacyjnej, promocyjnej, konsultacyjnej i usługowej. Jak stwierdzono wyżej, funkcje usługowa i konsultacyjna raczej powinny znaleźć się w BIP-ie, zatem w badaniu zwrócono uwagę na funkcje informacyjną i promocyjną, o czym dalej.

Internet, jako sieć połączonych komputerów, jest niewątpliwie środkiem komunikowania (Goban-Klas, Sienkiewicz, 1999, s. 13). Jest także najtańszym i najszybszym sposobem komunikowania. Informacje zamieszczone na stronie internetowej są natychmiast przekazywane, mogą być na bieżąco aktualizowane (Langer, 2008, s. 155), stąd też uważa się Internet za medium idealne dla PR (Brady, Forrest, Mizerski, 2002, s. 150).

Małgorzata Komorowska i Krzysztof Kubiak w 2011 roku przeprowadzili badania pt. „Społeczna recepcja public relations”. Na pytanie - któ- 
re z narzędzi wykorzystujesz przy poszukiwaniu informacji o produkcie? $-72 \%$ respondentów wskazało witrynę WWW, 47\% fora internetowe, $19 \%$ konta firmowe w portalach społecznościowych (Komorowska, Kubiak, 2013, s. 163). Należy przypuszczać, że w przypadku promocji samorządów wyniki byłyby podobne, $\mathrm{z}$ wyjątkiem forów, gdyż takie po prostu nie istnieja. Z przytoczonych wyżej badań K. Marcinkowskiego (2008, s. 198) wynika, że gminy, które przeprowadzały analizę efektywności swoich działań PR, wskazały Internet jako instrument najskuteczniejszy.

Zakres wykorzystania Internetu dzieli się historycznie na dwa etapy. Starsza wersja stanowiła jedynie nowy kanał przekazywania treści, który opierał się głównie na stronach WWW lub wykorzystaniu poczty elektronicznej w celu rozsyłania e-maili. Wersja 2.0 pojawiła się około 2003 roku i sprowadzała się do hasła „,interaktywność”. Rozpoczęło się aktywizowanie dotychczas pasywnego odbiorcy, który stał się także twórcą ,kontentu” (Lakomy, 2013, s. 45-46). Otworzyły się nowe możliwości dla działań PR, w tym także dla organów administracji (Konieczka, 2012, s. 303).

Nieodłączną częścią Internetu 2.0 są social media, które to środki przekazu podlegają (jedynie) kontroli społecznej i które mogą być wykorzystywane do komunikacji na dowolną skalę (Kaznowski, 2010). W mediach tradycyjnych informacje były emitowane przez nadawcę (publikatora) i żyły swoim życiem, często zależnym od cyklu wydawniczego (dziennik, tygodnik itd.). W mediach społecznych lub społecznościowych (Kaczmarek-Śliwińska, 2013, s. 27-32; Myers, 2012, s. 340) zamieszczenie informacji w Internecie może być impulsem do dalszej jej ewolucji (przerabiania, komentowania, przesyłania itp.). Pierwotna informacja może być modyfikowana w nieskończoność (w czasie i przestrzeni) przez niezliczoną liczbę kolejnych twórców (Kaznowski, 2013).

Prywatne przedsiębiorstwa i osoby fizyczne mają prawną swobodę zawierania umów, w tym także w Internecie. Organy władzy (w tym samorządy) muszą działać w granicach prawa. W Polsce nie ma żadnych uregulowań dotyczących korzystania przez władze z mediów społecznościowych. O ile w przypadku zakładania zwykłych stron internetowych należy stosować procedury zamówień publicznych (np. usługa hostingu, wykonanie strony itd.) (Konieczka, 2013, s. 305), to w przypadku Facebooka czy YouTube'a nie są znane przypadki ogłoszenia przetargu na świadczenie tego typu usług ${ }^{1}$.

1 Problemy prawne związane $\mathrm{z}$ funkcjonowaniem organów władzy w mediach społecznościowych są jednym z głównych tematów portalu vagla.pl. 
Pomijając wątek prawny, należy stwierdzić, że urzędy coraz aktywniej uczestniczą w mediach społecznościowych. W 2011 roku na 39 polskich miast powyżej 100 tys. mieszkańców 24 było obecnych w social media, a najpopularniejszy był serwis YouTube (19) i Facebook (17) (Myers, 2013, s. 347-348). Swoje profile lub fanpage na Facebooku mają także liderzy lokalni lub kandydaci w wyborach (Piechota, 2013, s. 15).

\section{Problem badawczy i metodologia}

Jak twierdzi Magdalena Tabernacka (2013, s. 470): „Działania polegające na promocji gminy nie są prowadzone po to, by zaspokoić potrzeby określonego urzędu czy instytucji publicznych zlokalizowanych w danej jednostce samorządu terytorialnego, tylko są to działania, które mają być prowadzone na rzecz określonej wspólnoty zamieszkującej dane terytorium".

Powszechną jest opinia, że urzędującemu wójtowi łatwiej jest wygrać wybory, gdyż ma już jakieś osiągnięcia i każdy go zna, a także ma aparat urzędniczy i medialny, który może wykorzystać. W małych gminach, gdzie najczęściej nie ma żadnych mediów niezależnych (lokalnej lub sublokalnej prasy drukowanej, portalu informacyjnego) władze gminy posiadają monopol informacyjny. Generalnie wykorzystywane są dwa kanały komunikacyjne: strony internetowe urzędów i gazety gminne. Co jakiś czas podnoszone są zarzuty o legalność działań urzędów gmin w tym zakresie - czy gminy mogą wydawać prasę, która de facto służy autopromocji władz, czy mogą zamieszczać w niej reklamy, czy nie stanowią konkurencji dla prywatnych podmiotów itd. ${ }^{2} \mathrm{Na}$ temat działalności gminnych serwisów internetowych jeszcze nie rozpoczęto dyskusji, ale nie wykluczone, że także i ta forma aktywności gmin może trafić pod lupę urzędów kontroli (o wątpliwościach pisano wyżej).

$\mathrm{W}$ badaniu postanowiono sprawdzić czy rzeczywiście serwisy internetowe promują urzędujących wójtów. Do badania wylosowano 40 gmin, z tego 15 miejsko-wiejskich i 25 wiejskich. W Polsce wg stanu z 1 stycznia 2015 roku jest 611 gmin miejsko-wiejskich i 1563 wiejskich. Próba badawcza wyniosła zatem 2,45\% gmin miejsko-wiejskich i 1,59\% wiejskich. Odsetek zatem jest niewielki i nie jest miarodajny dla całego kraju. Może jednak stanowić pierwszy krok do zbadania tego zjawiska.

2 Sprawy te porusza m.in. portalsamorzadowy.pl. Istnieją już także orzeczenia regionalnych izb obrachunkowych, kwestionujące zamieszczanie reklam i ogłoszeń. 
W okresie między 1 września a 31 grudnia 2014 roku analizowano zawartość stron internetowych wylosowanych gmin. Zastosowano metodę ilościową oraz jakościową. Badano tylko artykuły (posty) zamieszczane na stronie głównej serwisów w dziale aktualności, bez zaglądania na inne, często bardzo rozbudowane działy i zakładki. Poszczególne artykuły przyporządkowano do następujących kategorii: materiały urzędowe (własne lub pochodzące od innych urzędów lub instytucji państwowych), imprezy/wydarzenia (w tym sportowe, kulturalne, odbywające się na terenie gminy lub organizowane przez urząd lub jednostki podległe), imprezy z wójtem (jak poprzednio, ale z wyraźnym zaznaczeniem w treści artykułu lub materiale zdjęciowym, że w danym wydarzeniu uczestniczył wójt), życzenia (także kondolencje od wójta/urzędu), o nas (informacje o gminie/wójcie zamieszczane w prasie zewnętrznej, także nagrody i wyróżnienia dla gminy/wójta), inwestycje (także remonty, pozyskane fundusze itp.), inwestycje z wójtem (jak poprzednio, z wyraźnym zaznaczeniem roli wójta), inne (niemieszczące się w poprzednich kategoriach), inne $\mathrm{z}$ wójtem.

Okres badania wynosił 85 dni roboczych, nie licząc dni wolnych od pracy. W tym czasie wypadały także dni świąteczne (w tym święta państwowe), które można było wykorzystać z punktu widzenia promocji kandydata. Niektóre święta jak np. Dzień Edukacji Narodowej czy Dzień Pracownika Socjalnego wybitnie nadają się do wykorzystania przez wójta w kampanii.

W drugiej części badania zwrócono uwagę na obecność gmin w serwisie społecznościowym Facebook. Brano pod uwagę jednak tylko oficjalne konta, do których odnośnik był umieszczony w serwisie gminnym. Badano głównie korelację postów na Facebooku z oficjalnymi stronami.

Głównym problemem w badaniu okazała się zmienność zawartości. W kilku przypadkach, po przegranych wyborach przez dotychczasowego wójta, nowy wójt dokonywał czystki w artykułach poprzednika lub wręcz zmieniał wygląd strony nie archiwizując poprzedniej. Wówczas starano się odtworzyć pierwotną zawartość, korzystając z archiwum internetowego (archive.org/web). Nie w każdym przypadku było to możliwe. Usuniętych postów z Facebooka nie można odtworzyć, zatem tutaj musiała wystarczyć obserwacja bieżąca. Gmina Czarnożyły w trakcie badania zmieniła wygląd strony (burmistrz pozostał ten sam). Zaimportowano co prawda informacje $\mathrm{z}$ lat poprzednich, ale skasowano umieszczone pierwotnie między 15 grudnia 2013 a 3 listopada 2014 r., a oryginalna strona jest nie do odtworzenia. Z kolei w Gminie Daleszyce zmienił się 
burmistrz i pierwsza informacja, która jest dostępna na stronie nosi datę 2 grudnia 2014 r. Poprzednie skasowano i są nie do odzyskania. W miejsce tych dwu gmin wylosowano kolejne.

\section{Omówienie wyników}

Częstotliwość wpisów na stronach urzędów nie jest zadowalająca. Jak pisano wyżej, w ciągu 85 dni (7 tygodni) wypadało kilka świąt, które są obchodzone $\mathrm{w}$ gminach i z których relacje powinny znaleźć się na stronie internetowej. Do obowiązkowych wręcz należy zaliczyć rozpoczęcie roku szkolnego, Dzień Edukacji Narodowej, Święto Niepodległości. Okazjami do zaistnienia są także dożynki (szczególnie w gminach wiejskich), Mikołajki, Sylwester/Nowy Rok, Dzień Seniora, Dzień Pracownika Socjalnego, zainicjowane przez Prezydenta RP czytanie Sienkiewicza itd. Wśród gmin wiejskich 36\% dokonuje wpisów przynajmniej raz w tygodniu, $8 \%$ rzadziej niż raz w tygodniu, 28\% średnio co drugi dzień i $28 \%$ co najmniej raz dziennie. Wśród gmin miejsko-wiejskich sytuacja wygląda zdecydowanie lepiej: 47\% gmin aktualizuje strony co najmniej raz dziennie, a 53\% nie rzadziej niż raz na dwa dni. Przerwy dłuższe niż trzy dni nie zdarzają się. Wyniki korespondują z badaniami Patrycji Szostok i Rafała Rajczyka (2013, s. 119-121), którzy również (co prawda na podstawie deklaracji urzędników) doszli do wniosku, że im mniejsza gmina, tym rzadsze aktualizowanie stron. Zdaniem autorów przyczyną tego stanu rzeczy może być po prostu mniejsza liczba wydarzeń wartych odnotowania w Internecie. Nie wydaje się to słuszne, gdyż przy kwestionariuszu zastosowanym w niniejszym badaniu, nawet przy „martwym” w wydarzenia okresie, licznik wpisów można było nadrobić materiałami urzędowymi np. dotyczącymi wyborów. Tym bardziej, że w gminach wiejskich do kategorii „materiały urzędowe” zaliczano np. komunikaty Agencji Rozwoju i Modernizacji Rolnictwa. Drugim sposobem poprawienia średniej wpisów były ,życzenia”. Urzędnicy nie skorzystali z tej możliwości, o czym dalej.

W 12 gminach wiejskich (48\%) informacje w kategorii „urzędowe” stanowiły największy odsetek. W niektórych gminach wiadomości urzędowe stanowiły ponad połowę wszystkich wpisów (Jasionówka 65\%, Nowa Brzeźnica 59\%, Cyców 53\%, Sawin 67\%, Brójce 62,5\%, Szczaniec 55\%). W gminach miejsko-wiejskich urzędowe informacje ,wygrały” w 7 na 15 przypadków (47\%), z tym że tylko w Miasteczku Śląskim 
stanowiły większość (53\%). Należy zaznaczyć, że wszystkie badane gminy posiadają Biuletyn Informacji Publicznej, zatem duża część (jeżeli nie większość) materiałów mogłaby być zamieszczana na stronach BIP.

Wiadomości w kategorii „,imprezy/wydarzenia” zajęły pierwsze miejsca w gminach wiejskich: Nadarzyn (43\%), Kostomłoty (40\%), Kadzidło (29\%), Miłkowice (58\%), Morawica (47,5\%), Drwinia (27\%) i Wiśniowa (59\%). Z kolei w gminach miejsko-wiejskich najwięcej wskazań było w: Żmigrodzie (29\%), Krośniewicach (52\%), Grodkowie (48\%), Goniądzu (35\%) i Goleniowie (45\%). Wydaje się, że te gminy najpełniej wykorzystywały swoje strony w funkcji promocyjnej.

Zaledwie w dwóch gminach najwięcej wpisów dotyczyło inwestycji, były to: gminy wiejska Przybiernów (43\%) i miejsko-wiejska Środa Wielkopolska (35\%). Zaznaczyć jednak trzeba, że obie gminy należą do grupy z najmniejszą liczbą wpisów ogółem (Przybiernów 28, a Środa 71).

Kluczowe dla badania są wskazania w kategoriach związanych bezpośrednio z wójtem (burmistrzem). Wyniki dla gmin wiejskich prezentuje tabela 1, a dla gmin miejsko-wiejskich tabela 2.

Tabela 1

Odsetek artykułów $\mathrm{z}$ wójtem na stronach internetowych gmin wiejskich

\begin{tabular}{|l|c|c|c||}
\hline \multicolumn{1}{|c|}{ Gmina } & $\begin{array}{c}\text { Artykuly z wójtem } \\
\text { przed rozstrzygnięciem } \\
\text { wyborczym [\%] }\end{array}$ & $\begin{array}{c}\text { Artykuly z wójtem } \\
\text { ogólem [\%] }\end{array}$ & Artykuły ogólem \\
\hline \multicolumn{1}{|c|}{1} & 2 & 3 & 4 \\
\hline Jasionówka & 7 & 6 & 44 \\
\hline Miękinia & 33,3 & 27 & 100 \\
\hline Nadarzyn & 4,5 & 6 & 183 \\
\hline Radowo Małe & 33,3 & 20 & 5 \\
\hline Wagrowiec & 10,5 & 14 & 29 \\
\hline Nowa Brzeźnica & 0 & 0 & 17 \\
\hline Kostomłoty & 15 & 10 & 47 \\
\hline Kadzidło & 21 & 20 & 111 \\
\hline Sawin & 4,5 & 5 & 84 \\
\hline Czernikowo & 14 & 9,5 & 21 \\
\hline Wierzchowo & 5,5 & 3 & 63 \\
\hline Brójce & 0 & 0 & 24 \\
\hline Obrowo & 6 & 6 & 83 \\
\hline Zadzim & 10,2 & 10 & 112 \\
\hline Miłkowice & 0 & 0 & 41 \\
\hline Przybiernów & 0 & 0 & 28 \\
\hline Puck & 20 & 14 & 102 \\
\hline Sędziejowice & 7 & 7 & 43 \\
\hline & & & \\
\hline
\end{tabular}




\begin{tabular}{||l|c|c|c||}
\hline \multicolumn{1}{|c|}{1} & 2 & 3 & 4 \\
\hline Morawica & 16,3 & 11,5 & 160 \\
\hline Szczaniec & 0 & 0 & 9 \\
\hline Karsin & 76 & 62,5 & 24 \\
\hline Bytnica & 13,3 & 12,5 & 40 \\
\hline Drwinia & 14 & 11 & 113 \\
\hline Wiśniowa & 4 & 2,5 & 41 \\
\hline Cyców & 0 & 0 & 45 \\
\hline
\end{tabular}

Źródło: Opracowanie własne.

Tabela 2

Odsetek artykułów z burmistrzem na stronach internetowych gmin miejsko-wiejskich

\begin{tabular}{||l|c|c|c||}
\hline \multicolumn{1}{|c|}{ Gmina } & $\begin{array}{c}\text { Artykuły z wójtem } \\
\text { przed rozstrzygnięciem } \\
\text { wyborczym [\%] }\end{array}$ & $\begin{array}{c}\text { Artykuly } \\
\text { z burmistrzem } \\
\text { ogółem [\%] }\end{array}$ & $\begin{array}{c}\text { Artykuły } \\
\text { ogólem }\end{array}$ \\
\hline Oborniki & 34,2 & 27,4 & 222 \\
\hline Witkowo & 16 & 15,2 & 46 \\
\hline Węgorzewo & 9,6 & 8,5 & 141 \\
\hline Żmigród & 8,1 & 6,3 & 174 \\
\hline Książ Wielkopolski & 14 & 9,2 & 65 \\
\hline Nowa Sarzyna & 1 & 0,7 & 130 \\
\hline Krośniewice & 12,5 & 8,7 & 46 \\
\hline Grodków & 4 & 4 & 48 \\
\hline Miasteczko Śląskie & 7,8 & 6,3 & 710 \\
\hline Środa Wielkopolska & 14,3 & 15,5 & 55 \\
\hline Goniądz & 10 & 13 & 207 \\
\hline Goleniów & 6,5 & 7 & 64 \\
\hline Gryfice & 20 & 19 & 63 \\
\hline Mrozy & 12 & 8 & 210 \\
\hline Ogrodzieniec & 4,6 & 3,3 & \\
\hline
\end{tabular}

Źródło: Opracowanie własne.

Z obu tabel wynika, że w przypadku gmin wiejskich na 2 stronach, a gmin miejsko-wiejskich na czterech odsetek artykułów z wójtem (burmistrzem) był mniejszy przed wyborami w stosunku do ogółu opublikowanych. Gminy z małą liczbą artykułów należy pominąć, gdyż jeden czy dwa artykuły mogą stanowić dziesiątki procent. Jednak i tu można zauważyć prawidłowość. Przykładem jest gmina Karsin, która rzadko zamieszcza informacje na stronie, ale jeżeli już coś się pojawia, to w większości przypadków będzie to informacja o wójcie (w dodatku ze zdjęciem). W gminach wiejskich na czoło wybija się Morawica, gdzie 
wójt jest bardzo aktywny, a sama gmina jest laureatem wielu konkursów ogólnopolskich (np. „Złota Setka Samorządów”), stąd też w tak wielu artykułach pojawiają się wzmianki o wójcie. Warto też zaznaczyć, że nie sposób nie zauważyć, kto jest wójtem tej gminy, gdyż zdjęcie wójta wraz z przywitaniem znajduje się na stronie głównej portalu. Portalowy charakter ma także strona gminy Oborniki, która ewidentnie służy promocji burmistrza. Także strona Środy Wielkopolskiej przypomina portal, a materiały na niej zamieszczane są jak artykuły prasowe (np. każdy jest podpisany, co sporadycznie wychodziło w badaniu).

Jak widać w tabelach, rozpiętość w odsetku artykułów poświęconych włodarzom gmin jest bardzo duża. Wyjaśnieniu tego fenomenu nie pomoże także informacja o wynikach wyborów. W kilku gminach doszło do zmiany wójta, były to gminy Miłkowice (I tura), Sawin (II tura), Kostomłoty (I tura), Cyców (wójt nie startował), Zadzim (I tura), Szczaniec (II tura), Radowo Małe (II tura). Łaska wyborcy na pstrym koniu jeździ - wójtowie zostali odwołani w gminach, gdzie nic się nie działo (przynajmniej nie chwalono się tym w Internecie) jak w Radowie czy Szczańcu, ale także w Zadzimiu, gdzie 10\% artykułów było poświęconych wójtowi. Chociaż tu akurat średnia została utrzymana i widać z tego, że nowy wójt nie zrezygnował $\mathrm{z}$ autopromocji.

W drugiej części badania zwrócono się w stronę Facebooka. Okazało się, że swoje profile (fanpage) miały następujące gminy wiejskie: Morawica, Wierzchowo, Sawin, Kadzidło, Nadarzyn, Miękinia, Mrozy oraz wiejsko-miejskie: Środa Wielkopolska, Oborniki, Ogrodzieniec, Nowa Sarzyna, Żmigród. O ile w przypadku gmin wiejskich tak mała liczba jest raczej zrozumiała, gdyż na wsiach wszyscy się znają, a jak pokazało badanie wcześniejsze - nawet oficjalne strony są rzadko aktualizowane. Natomiast gminy miejsko-wiejskie rozczarowują, na Facebooku jest obecnych 5 spośród 15 badanych gmin, z tego Środa Wielkopolska dokonała tylko jednego wpisu w czasie badania (3 października 2014 roku). Z 12 gmin, utrzymujących profile w ośmiu coś się dzieje, tzn. ich administratorzy zamieszczają wpisy. Są to gminy: Mrozy (30 postów), Żmigród (35), Sawin (31), Kadzidło (15), Oborniki (23), Nadarzyn (35), Miękinia (26) i Ogrodzieniec (50).

Najlepiej funkcję promocyjną wypełnia strona Ogrodzieńca. Oprócz zamieszczania informacji własnych (w tym zdjęć i plakatów), co robią wszystkie profile, ten dodatkowo linkuje posty z własnej strony internetowej, a także do gminnego domu kultury (taka praktyka była tylko tutaj). Co więcej, zdarzały się także linki do innego serwisu społecznościowego (YouTube), strony BIP oraz do stron niezwiązanych z gmina, jak np. pry- 
watne gazety lokalne. Można stwierdzić, że fanpage gminy Ogrodzieniec jest prawdziwie społecznościowy. W ostatnim dniu 2014 roku administrator podlinkował życzenia zamieszczone na profilu burmistrza. Wchodząc tam, można wyczytać taką informację o właścicielu: „Oficjalna strona Burmistrza Miasta i Gminy Ogrodzieniec Andrzeja Mikulskiego" wraz z adresem strony internetowej: www.ogrodzieniec.pl. Jest to pewien dysonans, gdyż na fanpage'u gminy nie ma podanej informacji o właścicielu (urzędzie), godzinach pracy, czy osobie odpowiedzialnej za profil. Gdyby nie odpowiedni box na gminnej stronie internetowej, który przekierowuje na fanpage, użytkownik Facebooka mógłby mieć problemy z rozpoznaniem właściwego profilu gminy (wyszukiwarka wskazuje kilka Ogrodzieńców).

\section{Podsumowanie}

Przeprowadzone badanie nie wskazało jednoznacznych wyników. Badanie roli Facebooka w promocji gmin okazało się porażką, ze względu na małą liczbę profili oraz postów na nich zamieszczanych, a także problemów metodologicznych związanych z brakiem archiwizacji postów.

Natomiast w przypadku stron internetowych można stwierdzić, że około $10 \%$ artykułów publikowanych na gminnych stronach bezpośrednio związanych jest z włodarzami gmin. Im gmina bardziej się rozwija, ma dużo inwestycji, wówczas więcej jest powodów do pochwalenia się personalnie - sukces ma twarz wójta. I przeciwnie - jak gmina jest w marazmie i stagnacji, to wtedy nie ma o czym pisać. Wydaje się, że - jak we wszystkim - wskazany jest umiar. Przykład Obornik, w których portalu aż 34\% artykułów w okresie przedwyborczym było poświęconych burmistrzowi, powinien być jednak wskazówką postępowania niepożądanego. Aby osiągnąć miarodajne wyniki, należałoby zwiększyć próbę badawczą.

\section{Bibliografia}

Bartkowski J. (2007), Mechanizmy ksztaltowania się wyboru politycznego na szczeblu lokalnym, w: Marketing polityczny - szanse czy zagrożenie dla wspótczesnej demokracji?, red. P. Pawełczyk, Wydawnictwo Naukowe Instytutu Nauk Politycznych i Dziennikarstwa Uniwersytetu im. Adama Mickiewicza, Poznań.

Brady R., Forrest E., Mizerski R. (2002), Marketing w Internecie, Polskie Wydawnictwo Ekonomiczne, Warszawa. 
Butkiewicz M. (2006), Internet w instytucjach publicznych. Zagadnienia prawne, Difin, Warszawa.

Cwalina W., Falkowski A. (2005), Marketing polityczny. Perspektywa psychologiczna, Gdańskie Wydawnictwo Psychologiczne, Gdańsk.

Czarnecka A. (2012), Wizerunek jako czynnik wzrostu konkurencyjności gminy, „Zeszyty Naukowe Uniwersytetu Szczecińskiego. Ekonomiczne Problemy Usług”, nr 724.

Dobek-Ostrowska B. (2011), Komunikowanie polityczne i publiczne. Podręcznik akademicki, Wydawnictwo Naukowe PWN, Warszawa.

Duczkowska-Piasecka M. (2013), Marketing terytorialny. Jak podejść do rozwoju z korzyścia dla wszystkich, Difin, Warszawa.

Duda A. (2010), Istota i rola public relations, w: Public relations miast i regionów, red. A. Duda, Difin, Warszawa.

Ferenc-Szydełko E. (2013), Prawo prasowe. Komentarz, LEX, Warszawa.

Folga R. (2014), Perspektywy $i$ wyzwania marketingu $w$ administracji publicznej w Polsce, w: Perspektywy rozwoju marketingu, red. K. Śliwińska, seria: „Zeszyty Naukowe Wydziałowe Uniwersytetu Ekonomicznego w Katowicach. Studia Ekonomiczne", z. 194, Katowice.

Gajowniczek T. (2013), Demokracja elektroniczna na przykładzie gmin powiatu olsztyńskiego, w: Demokracja elektroniczna. Kontrowersje i dylematy, red. M. Marczewska-Rytko, Wydawnictwo Uniwersytetu Marii Curie-Skłodowskiej, Lublin.

Goban-Klas T., Sienkiewicz P. (1999), Społeczeństwo informacyjne: Szanse, zagrożenia, wyzwania, Wydawnictwo Fundacji Postępu Telekomunikacji, Kraków.

Grzybowski M. (2005), Administracja publiczna a ład konstytucyjny, w: Administracja publiczna, red. J. Hausner, Wydawnictwo Naukowe PWN, Warszawa.

Kaczmarek-Śliwińska M. (2013), Public relations $w$ przestrzeni mediów społecznościowych. Działania organizacji i jej pracowników, Wydawnictwo Politechniki Koszalińskiej, Koszalin.

Kaznowski D. (2010), Definicja social media, 17.04.2010, Networked Digital Age, http://networkeddigital.com/2010/04/17/definicja-social-media/.

Kaznowski D. (2013), Social media - społeczny wymiar Internetu, w: E-marketing. Wspótczesne trendy. Pakiet startowy, red. J. Królewski, P. Sala, Wydawnictwo Naukowe PWN, Warszawa.

Knecht Z. (2006), Public relations $w$ administracji publicznej. Teoria, praktyka, badania, C.H. Beck, Warszawa.

Kolbus B. M. (2013), Podstawy marketingowego zarzadzania miastem. Teoria i przykłady, w: Public relations. Nowe trendy, red. K. Stasiuk-Krajewska, Z. Chmielewski, D. Tworzydło, Newsline.pl, Rzeszów.

Komorowska M., Kubiak K. (2013), Społeczna recepcja interactive public relations, w: Public relations. Nowe trendy, red. K. Stasiuk-Krajewska, Z. Chmielewski, D. Tworzydło, Newsline.pl, Rzeszów. 
Konieczka L. (2012), Narzędzia stużqce do prowadzenia działań public relations na stronach internetowych administracji publicznej, w: Public relations $w$ sferze publicznej. Wizerunek i komunikacja, red. M. Tabernacka, A. Szadok-Bratuń, LEX, Warszawa.

Kowalczyk M. (2009), E-urzqd w komunikacji z obywatelem, Wydawnictwa Akademickie i Profesjonalne, Warszawa.

Krawczyk A. (2014), Internet w komunikowaniu publicznym gmin województwa ślaskiego, Uniwersytet Śląski, Katowice, mps pr. dr.

Lakomy M. (2013), Demokracja 2.0. Interakcja polityczna w nowych mediach. Dyskurs politologiczny, Akademia Ignatianum - Wydawnictwo WAM, Kraków.

Langer W. (2008), Kreowanie wizerunku jednostki terytorialnej. Studia przypadków, w: Public relations w czasach MP3 i Internetu, red. D. Tworzydło, Z. Chmielewski, Wydawnictwo Wyższej Szkoły Informatyki i Zarządzania, Rzeszów.

Marcinkowski K. (2008), Samorzqdowe public relations $w$ gminach powiatu poznańskiego - doniesienie z badań, w: Public relations w czasach MP3 i Internetu, red. D. Tworzydło, Z. Chmielewski, Wydawnictwo Wyższej Szkoły Informatyki i Zarządzania, Rzeszów.

Marjak H. (2008), Metody oceny $i$ walidacji stron internetowych, w: Innowacje i innowacyjność w sektorze agrobiznesu, red. M. Adamowicz, seria: „Prace Naukowe SGGW" nr 45, Warszawa.

Myers B. (2012), Wykorzystanie mediów społecznościowych do działań public relations na stronach internetowych jednostek samorzqdów lokalnych-przyszłość komunikacji z obywatelem?, w: Public relations w sferze publicznej. Wizerunek i komunikacja, red. M. Tabernacka, A. Szadok-Bratuń, LEX, Warszawa.

Nowina Konopka M. (2011), Wykorzystanie Internetu do realizacji zadań $P R$ w administracji publicznej, w: Nowe media w systemie komunikowania: polityka, red. M. Jeziński, Wydawnictwo Adam Marszałek, Toruń.

Piasecki A. K. (2009), Samorzqd terytorialny $i$ wspólnoty lokalne, Wydawnictwo Naukowe PWN, Warszawa.

Piasecki A. K. (2007), Czy wójtowi potrzebny jest marketing polityczny? Teoria i praktyka zastosowania marketingu przez liderów lokalnych wspólnot, w: Marketing polityczny - szanse czy zagrożenie dla współczesnej demokracji?, red. P. Pawełczyk, Wydawnictwo Naukowe Instytutu Nauk Politycznych i Dziennikarstwa Uniwersytetu im. Adama Mickiewicza, Poznań.

Piechota G. (2013), Zmiana paradygmatu w komunikowaniu lokalnym? Propaganda versus technologia, w: Lokalne komunikowanie polityczne, red. W. Furman, P. Kuca, Wydawnictwo Uniwersytetu Rzeszowskiego, Rzeszów.

Piontek D. (2003), Imagistyka społeczna, czyli marketing polityczny, w: Media masowe w systemach demokratycznych. Teoretyczne problemy i praktyczny wymiar komunikowania politycznego, red. B. Dobek-Ostrowska, Dolnośląska Szkoła Wyższa Edukacji Towarzystwa Wiedzy Powszechnej, Wrocław 2003.

Przech R., Public relations w administracji publicznej w Polsce. Wyniki badań i perspektywy rozwoju, 11.12.2007, PRoto.pl, http://www.proto.pl/artykuly/public-relationsw-administracji-publicznej-w-polsce-wyniki-badan-i-perspektywy-rozwoju. 
Przepióra S. (2013), Rola wybranych narzędzi PR w ksztattowaniu wizerunku miast. Subiektywny przeglad najciekawszych kampanii promocyjnych polskich miast, w: Public relations - nie tylko Facebook, red. K. Stasiuk-Krajewska, D. Tworzydło, Z. Chmielewski, Newsline.pl, Rzeszów.

Szostok P., Ratajczyk R. (2013), Komunikowanie lokalne w Polsce. O instrumentach polityki komunikacyjnej samorzqdów, Wydawnictwo Gnome, Katowice.

Szymańska A. (2006), Zintegrowane komunikowanie marketingowe, w: Public relations. Znaczenie społeczne i kierunki rozwoju, red. J. Olędzki, D. Tworzywo, Wydawnictwo Naukowe PWN, Warszawa.

Tabernacka M. (2013), Narzędzia komunikacyjne public relations $w$ administracji publicznej, w: Public relations $w$ sferze publicznej. Wizerunek i komunikacja, red. M. Tabernacka, A. Szadok-Bratuń, LEX, Warszawa.

UDIP - Ustawa z dnia 6 września 2001 r. o dostępie do informacji publicznej, Dz. U. 2014, poz. 782 .

Zieliński J. (2013), Marketing polityczny w Internecie, Wydawnictwo Adam Marszałek, Toruń.

\section{Badane strony:}

\section{Gminy wiejskie:}

Brójce, http://brojce.pl/.

Bytnica, http://bytnica.pl/.

Cyców, http://ugcycow.pl/.

Czernikowo, http://www.czernikowo.pl/.

Drwinia, http://www.drwinia.pl/.

Jasionówka, http://www.jasionowka.pl.

Kadzidło, http://www.kadzidlo.pl.

Karsin, http://www.karsin.pl/.

Kostomłoty, http://kostomloty.pl/.

Miękinia, http://www.miekinia.pl/pl/.

Miłkowice, http://www.ugmilkowice.net/.

Morawica, http://www.morawica.pl/.

Nadarzyn, http://www.nadarzyn.pl/.

Nowa Brzeźnica, http://www.nowabrzeznica.pl/.

Obrowo, http://www.obrowo.pl/.

Przybiernów, http://www.przybiernow.pl.

Puck, http://gmina.puck.pl/.

Radowo Małe, http://radowomale.pl/.

Sawin, http://radowomale.pl/.

Sędziejowice, http://gminasedziejowice.eu/.

Szczaniec, http://www.szczaniec.pl/. 
Wagrowiec, http://www.gminawagrowiec.pl/.

Wierzchowo, http://www.wierzchowo.pl/.

Wiśniowa, http://www.ug-wisniowa.pl/.

Zadzim, http://gminazadzim.pl/.

\section{Gminy miejsko-wiejskie:}

Goleniów, http://www.goleniow.pl/.

Goniądz, http://www.goniadz.pl/.

Grodków, http://grodkow.pl/.

Gryfice, http://www.gryfice.eu/.

Krośniewice, http://krosniewice.pl/.

Książ Wielkopolski, http://ksiaz-wlkp.pl/.

Miasteczko Śląskie, http://miasteczko-slaskie.pl/.

Mrozy, http://mrozy.pl.

Nowa Sarzyna, http://nowasarzyna.eu/.

Oborniki, http://www.oborniki.pl/

Ogrodzieniec, http://www.ogrodzieniec.pl/.

Środa Wielkopolska, http://sroda.wlkp.pl/.

Węgorzewo, http://www.3.wegorzewo.pl/.

Witkowo. http://witkowo.pl/.

Żmigród. http://zmigrod.com.pl/.

The Internet in the service of the local government or the local politicians? Based on the content of websites of small municipalities in the local election campaign in 2014

\section{Summary}

It is a common opinion that a candidate holding public office finds it easier to win the election. He or she already has some achievements, and the electorate knows them. The candidate can also use the subordinate administrative apparatus in the electoral campaign. The article presents the results of content analysis of the websites of small municipalities during the election campaign in 2014. It attempts to answer the following question: Do websites of local governments promote municipalities, or are they treated instrumentally by mayors in office for self-promotion purposes?

Key words: local government, the Internet, electoral campaign, political marketing, PR 